medRxiv preprint doi: https://doi.org/10.1101/2022.02.07.22270566; this version posted February 9, 2022. The copyright holder for this preprint (which was not certified by peer review) is the author/funder, who has granted medRxiv a license to display the preprint in perpetuity. It is made available under a CC-BY-NC-ND 4.0 International license .

Yajnik \& Tan et al. Determinants of Neurocognitive Development in Children

\title{
Title: Robust Determinants of Neurocognitive Development in Children: Evidence from the Pune Maternal Nutrition Study (PMNS)
}

Short title: Determinants of Neurocognitive Development in Children

$$
\text { Chittaranjan S. Yajnik }{ }^{1 \dagger^{*}} \text {, Chih Ming Tan }{ }^{2 \dagger *} \text {, Vidya Bhate }{ }^{1,5} \text {, Souvik Bandyopadhyay }{ }^{3} \text {, }
$$
Ashwini Sankar ${ }^{4}$, Rishikesh V. Behere ${ }^{1}$

1 -Diabetes Unit, KEM Hospital Research Center, Pune, India

2 - Department of Economics \& Finance, Nistler College of Business and Public

Administration, University of North Dakota, Grand Forks, USA.

3 - Strategic Consultant, Cytel, Inc, Bengaluru, India.

4 - Carlson School of Management, University of Minnesota-Twin Cities, USA

5 - Department of Psychology, Vishwakarma University, Pune, India

† Joint first and corresponding authors

\section{* Corresponding authors}

Dr Chittaranjan S Yajnik

Director, Diabetes Unit

KEM Hospital Research Center

489, Rasta Peth

Pune - 411011, India

Email: csyajnik@gmail.com

Ph: +919822847481

Dr Chih Ming Tan

Department of Economics \& Finance, Nistler College of Business and Public

Administration,

University of North Dakota,

Grand Forks, USA.

Email: chihming.tan@und.edu

Word Count: 4324 
medRxiv preprint doi: https://doi.org/10.1101/2022.02.07.22270566; this version posted February 9, 2022. The copyright holder for this preprint (which was not certified by peer review) is the author/funder, who has granted medRxiv a license to display the preprint in perpetuity. It is made available under a CC-BY-NC-ND 4.0 International license .

Yajnik \& Tan et al. Determinants of Neurocognitive Development in Children

Abstract

Neurocognitive development is a dynamic process over the life course and is influenced by intrauterine factors as well as later life environment. Using data from the Pune Maternal Nutrition Study (PMNS) from 1994 to 2008, we investigate the association of in-utero, birth, and childhood conditions with offspring neurocognitive development in 686 participants of the cohort, at age 12 years. The life course exposure variables in the analysis include maternal pre-pregnancy size and nutrition during pregnancy, offspring birth measurements, nutrition and physical growth at age 12 years along with parental education and socio-economic status. We used the novel Bayesian Model Averaging (BMA) approach; which has been shown to have better predictive performance over traditional tests of associations. Our study employs 8 standard neurocognitive tests that measure intelligence, working memory, visuo-conceptual and verbal learning, and decision-making/attention at 12 years of age. We control for nutritional-metabolic information based on blood measurements from the pregnant mothers and the children at 12 years of age. Our findings highlight the critical role of parental education and socioeconomic background in determining child neurocognitive performance. Maternal characteristics (pre-pregnancy BMI, fasting insulin during pregnancy) and child height at 12 years were also robust predictors on the BMA. A range of early factors - such as maternal folate and ferritin concentrations during pregnancy, and child's head circumference at birth - remained important determinants of some dimensions of child's neurocognitive development, but their associations were not robust once we account for model uncertainty. Our results suggest that intrauterine 
medRxiv preprint doi: https://doi.org/10.1101/2022.02.07.22270566; this version posted February 9, 2022. The copyright holder for this preprint (which was not certified by peer review) is the author/funder, who has granted medRxiv a license to display the preprint in perpetuity. It is made available under a CC-BY-NC-ND 4.0 International license.

Yajnik \& Tan et al. Determinants of Neurocognitive Development in Children

influences on long term neurocognitive outcomes may be potentially reversible by post birth remediation. In addition to the current nutritional interventions, public health policy should also consider social interventions in children born into families with low socioeconomic status to improve human capital.

Keywords: Neurocognitive development, Parental education, Life-course exposures, Bayesian Model Averaging, 
medRxiv preprint doi: https://doi.org/10.1101/2022.02.07.22270566; this version posted February 9, 2022. The copyright holder for this preprint (which was not certified by peer review) is the author/funder, who has granted medRxiv a license to display the preprint in perpetuity. It is made available under a CC-BY-NC-ND 4.0 International license .

Yajnik \& Tan et al. Determinants of Neurocognitive Development in Children

\section{Introduction}

Fetal and childhood growth and development are important determinants of adult health and human capital ${ }^{1-3}$. Neurodevelopment is a dynamic process and is influenced by genetic and environmental factors over the life course of an individual. In this model, intrauterine (including maternal nutrition and metabolism) and post-natal environment (events at birth, childhood illness, nutrition, socio-economic environment, education) have crucial influence. This is the central theme of the concept of Developmental Origins of Health and Disease (DOHaD).

Exposure of the fetus to adverse developmental influences such as famine during pregnancy (proxy for maternal-fetal undernourishment), maternal diabetes and poor socio-economic conditions have been studied in many populations, ${ }^{4-8}$ and shown to result in negative impacts on a range of health outcomes including neurocognitive outcomes $^{9}$. Maternal macronutrient (glucose, lipids, amino acids) and micronutrient nutrition (Vitamins B12, folate, D and C, pyridoxine, and Iron) influence offspring neurocognitive development ${ }^{10}$. Low maternal folate and vitamin B12 are associated with neural tube defects ${ }^{11}$, developmental delays and autistic spectrum disorders ${ }^{12}$. Babies born with Low Birth Weight (LBW), Small for Gestational Age (SGA) or Intrauterine Growth Restriction (IUGR) and those born pre-term have lower neurocognitive functioning scores in childhood ${ }^{13}$. In prospective follow up studies in our birth cohorts we observed lower maternal B12 status during pregnancy to be associated with impaired neurocognitive performance of the offspring at 2 years ${ }^{14}$ and 9 years of 
medRxiv preprint doi: https://doi.org/10.1101/2022.02.07.22270566; this version posted February 9, 2022. The copyright holder for this preprint (which was not certified by peer review) is the author/funder, who has granted medRxiv a license to display the preprint in perpetuity. It is made available under a CC-BY-NC-ND 4.0 International license .

Yajnik \& Tan et al. Determinants of Neurocognitive Development in Children

age $^{15}$. Poverty can lead to poor maternal nutrition, increased maternal stress and growth restriction and stunting in the offspring ${ }^{16}$. These factors have been associated with neurocognitive impairment, poorer school performance, and underachievement in adulthood which may lead to a perpetual intergenerational cycle of deprivation and impaired development $^{17,18}$.

The Pune Maternal Nutrition Study (PMNS) investigated nutritional and physiological determinants of fetal growth in a rural environment. The children born in this birth cohort have been followed up for their physical and neurocognitive development. In this paper, we investigate the associations of in utero exposures (e.g., maternal nutrition and metabolism during pregnancy), birth size and post-natal factors (e.g., childhood nutrition, growth and development), as well as parental education and family socioeconomic status with offspring neurocognitive development at age 12 years. Our work is novel in two ways. First, availability of prospective phenotypic data in the PMNS allows us to investigate the association of not only initial shocks (intrauterine factors), but also subsequent remedial changes in nutritional and socio-economic status across the life course of the child (until age 12 when the child takes the neurocognitive tests). Second, our paper also introduces methodological advancements in terms of data analysis to this area of research. Instead of using a pre-selected set of "benchmark" regression models (implicitly introducing unspecified prior knowledge about the outcome process), we employ Bayesian model averaging (BMA) methods ${ }^{19}$ that, instead of relying on any single regression model, produce robust estimates by assigning evidentiary weights based on the data to each model in the model space, and then taking an average of model-specific estimates using these weights. There is 
medRxiv preprint doi: https://doi.org/10.1101/2022.02.07.22270566; this version posted February 9, 2022. The copyright holder for this preprint (which was not certified by peer review) is the author/funder, who has granted medRxiv a license to display the preprint in perpetuity. It is made available under a CC-BY-NC-ND 4.0 International license .

Yajnik \& Tan et al. Determinants of Neurocognitive Development in Children

considerable evidence that BMA performs better than using any single model; BMA point estimators and prediction intervals have been shown to minimize mean squared error, ${ }^{20}$ and BMA predictive distributions have optimal performance measured according to the logarithmic scoring rule. ${ }^{21}$

\section{Methods}

Data: The Pune Maternal Nutrition Study (PMNS) birth cohort

The Pune Maternal Nutrition Study (PMNS) is a preconception birth cohort ${ }^{22}$ established in 1993 at Diabetes Unit, KEM Hospital Research Centre, Pune, India. The PMNS investigated the role of maternal and paternal influences on fetal growth and has followed up the offspring to study the risk of non-communicable disease in later life. The detailed design is reported in Yajnik et al $(2008)^{23}$. In short, 2466 women in reproductive age group were recruited from the farming communities of 6 villages near Pune. Approximately 800 pregnancies were investigated in detail (18 and 28 weeks of gestation) for maternal nutritional intake on a food frequency questionnaire, ${ }^{24}$ physical activity, ${ }^{25}$ glucose tolerance, and circulating nutrient levels (vitamins B12, folate, C and D, pyridoxine and ferritin) and 762 live births occurred from June 1994 to April 1996. The babies were measured for size at birth. Using standard definitions ${ }^{26,27}$ based on birth weight and gestational age, Low Birth Weight (LBW) was defined as infants born with birth weight less than $2.5 \mathrm{kgs}$, Very Low Birth Weight (VLBW) as infants born with birth weight less than 2 kgs. Small for Gestational Age (SGA) was defined as less than 
medRxiv preprint doi: https://doi.org/10.1101/2022.02.07.22270566; this version posted February 9, 2022. The copyright holder for this preprint (which was not certified by peer review) is the author/funder, who has granted medRxiv a license to display the preprint in perpetuity. It is made available under a CC-BY-NC-ND 4.0 International license .

Yajnik \& Tan et al. Determinants of Neurocognitive Development in Children

$10^{\text {th }}$ centile of weight for gestational age. Preterm was defined as infants born at less than 37 weeks gestation.

The offspring were followed up every 6 months for physical growth. Every 6 years detailed cardio-metabolic measurements were made on parents and children. At 12 years of age, 686 (90\% of live) offspring were followed up for physical growth and development, cardio-metabolic risk factors, nutrition, circulating micronutrient concentrations and neurocognitive performance. Stunting in the children was defined as height less than 2 standard deviation of height for age. ${ }^{28}$ See Figure 1 for timelines in the PMNS and participant recruitment.

Biochemical measurements:

Biochemical measurements included hematological parameters, concentrations of circulating micronutrients and metabolic measurements in mothers during pregnancy

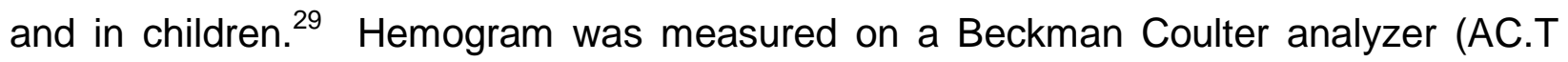
diffTM Analyzer, Florida, USA). Plasma vitamin B12 and red cell folate were measured using a microbiological assay technique. Total homocysteine was measured by HPLC (PerkinElmer 200 Series, PerkinElmer, Shelton, CT, USA). Plasma glucose was measured using an Hitachi 911 automated analyser (Hitachi, Tokyo, Japan) by the glucose oxidase peroxidase method. Plasma insulin was measured using a Delfia technique (Victor 2; Wallac, Turku, Finland).

Socioeconomic status assessment: 
medRxiv preprint doi: https://doi.org/10.1101/2022.02.07.22270566; this version posted February 9, 2022. The copyright holder for this preprint (which was not certified by peer review) is the author/funder, who has granted medRxiv a license to display the preprint in perpetuity. It is made available under a CC-BY-NC-ND 4.0 International license .

Yajnik \& Tan et al. Determinants of Neurocognitive Development in Children

The family's socioeconomic status (SES) was assessed using the Pareek and Trivedi Socio economic status scale ${ }^{30}$. This is a validated scale for assessment of SES in the Indian rural population. It comprehensively measures SES on dimensions of caste, education, occupation, land holding, social participation, family type, type of housing, farm and material possession. A total score is derived and higher score indicates a higher SES.

Neurocognitive measurements:

Data on our outcomes of interest were collected through neurocognitive assessments on 686 offspring at 12 years of age using 8 neuropsychological tests. The neurocognitive tests included Raven's Colored Progressive Matrices (CPM) that measures global neurocognitive ability, Block Design (BD) test that measures visuospatial processing, Picture Completion (PC) test that measures visual attention, Digit Span (Forward (DF) and Backward (DB)) tests that measure attention and working memory, Color Trail Making (2 test types; TM A and TM B) tests that measure focused and divided attention, and Auditory Verbal Learning Test (AVLT) that measures verbal learning and memory (see Appendix A for a detailed description of all the tests). Data for these 8 tests were collected and Indian normative percentiles and cut-off scores were used for scoring. ${ }^{31-34}$ For all tests a higher score indicates better neurocognitive functioning except TM A and TM B, where higher time taken indicates a poorer outcome.

Ethical considerations: 
medRxiv preprint doi: https://doi.org/10.1101/2022.02.07.22270566; this version posted February 9, 2022. The copyright holder for this preprint (which was not certified by peer review) is the author/funder, who has granted medRxiv a license to display the preprint in perpetuity. It is made available under a CC-BY-NC-ND 4.0 International license .

Yajnik \& Tan et al. Determinants of Neurocognitive Development in Children

Written informed consent was obtained from the parents, offspring provided assent. Permission to perform the study was obtained from the village community leaders and the Institutional Ethics Committee of KEM Hospital Research Center, Pune.

Statistical analysis

The purpose of our analysis was to determine the exposure variables over the life course significantly associated with cognitive outcomes at 12 years in the offspring. See tables $1 \& 2$ for a description of the dependent (outcome) and independent (exposure) variables used in this analysis. For maternal pregnancy exposures we used an average of measurements made at 18 and 28 weeks' gestation. All variables were transformed to $Z$ scores (by subtracting sample mean and dividing by the sample standard deviation for each variable). Height and weight for age $Z$ scores at birth were calculated using the INTERGROWTH criteria. ${ }^{35}$ Height and BMI for age $Z$ scores at 12 years were calculated according to the WHO reference 2007 using the WHO AnthroPlus software ${ }^{36}$ We then performed multivariate linear regression for each cognitive score as dependent variable. The significant associations are interpreted as the SD change (standardized beta coefficient) in cognitive score for one SD change in the exposure variable.

In addition to using the linear regression model, we used BMA methods to estimate the coefficients of interest, and to account for model uncertainty. We move away from using any "benchmark" specification, as is often used in this literature because of the inherently open-ended nature of explanations for outcomes of interest such as child neurocognitive development, where the validity of one particular theory of 
medRxiv preprint doi: https://doi.org/10.1101/2022.02.07.22270566; this version posted February 9, 2022. The copyright holder for this preprint (which was not certified by peer review) is the author/funder, who has granted medRxiv a license to display the preprint in perpetuity. It is made available under a CC-BY-NC-ND 4.0 International license .

Yajnik \& Tan et al. Determinants of Neurocognitive Development in Children

neurocognitive development (e.g., in utero malnutrition) does not logically exclude other theories from also being relevant (e.g., socioeconomic background). In fact, the possibility of concurrent multiple exposures is implied by the life course model.

BMA, begins by defining a model space that is generated from the set of covariates for the dependent variable. A model is simply a particular permutation of the set of covariates. To address model uncertainty, heuristically, BMA assigns an evidentiary weight (i.e., the posterior model probability) to each model in the model space given the data, and then calculates the posterior distribution of the parameter of interest (e.g., the effect of in-utero maternal B12 concentrations on neurocognitive outcomes) by averaging across the set of models in the model space using these evidentiary weights (see Appendix B for technical details of the model). BMA analysis was performed using all the life course variables to provide a posterior mean and posterior inclusion probability (PIP) for every individual cognitive score.

As is standard in the literature, we report the posterior mean for each coefficient. The posterior mean is taken in the literature to be the model-averaged coefficient estimate for the effect. We also report the square root of the posterior variance as the corresponding standard error. Finally, we also report the posterior inclusion probability (PIP), the sum of the posterior probabilities of models that include that variable, for each covariate, which is a standard way to conduct inference for each regressor (supplementary material Appendix B). The standard way to conduct inference in the context of BMA is to reference the PIP for each regressor. Following the guidance provided by literature ${ }^{37,38}$, we interpret a PIP $<50 \%$ as indicating a lack of evidence for an effect from that variable, a $50 \%<$ PIP $<75 \%$ as indicating weak evidence, a $75 \%<$ 
medRxiv preprint doi: https://doi.org/10.1101/2022.02.07.22270566; this version posted February 9, 2022. The copyright holder for this preprint (which was not certified by peer review) is the author/funder, who has granted medRxiv a license to display the preprint in perpetuity. It is made available under a CC-BY-NC-ND 4.0 International license .

Yajnik \& Tan et al. Determinants of Neurocognitive Development in Children

PIP $<95 \%$ as indicating positive evidence, a 95\% $<$ PIP $<99 \%$ as indicating strong evidence, and a $99 \%<$ PIP $<100 \%$ as indicating decisive evidence for an effect. Following standard practice ${ }^{39}$, we also report BMA posterior $t$ statistics for coefficient estimates and interpret them in the classical sense. For the BMA results we report posterior means and posterior SD for associations with a PIP > 75\%.

\section{Results}

The mothers were on average 21 years old with a BMl of $18.03 \pm 1.88 \mathrm{~kg} / \mathrm{m}^{2}$ at the start of their pregnancy (Table 1). The average years of education was $5.73 \pm 3.93$ years and $35 \%$ mothers had not completed primary school education. The proportion of mothers who were anaemic $(\mathrm{Hb}<10 \mathrm{gm} \%)$ was $17.3 \%$, average $\mathrm{B} 12$ level in mothers was $145.24 \pm 66.99 \mathrm{pM}$, and $65 \%$ of mothers were B12 deficient $(<150 \mathrm{pM})$. The mean Ferritin level in the mothers during pregnancy was $15.8 \pm 14.59 \mathrm{mcg} / \mathrm{l}$. All mothers were folate replete and $29 \%$ mothers had hyper-homocysteinemia (>10 mmol/L). Fathers had an average BMI of $19.44 \pm 2.54 \mathrm{~kg} / \mathrm{m}^{2}$ with $4 \%$ being overweight, $20 \%$ had not completed primary school education. The new-born children weighed an average of $2.63 \pm 0.37 \mathrm{kgs}, 37 \%$ of offspring were LBW and only 2 offspring were VLBW. 53\% offspring were SGA and $10 \%$ were born preterm. At 12 years $18 \%$ of the children showed stunting and $94 \%$ were under-weight. The mean years of schooling was $5.88 \pm$ 1.28 years. Only 5 out of the 686 children had dropped out of school. The cognitive test scores are provided in table-2. Boys performed better than girls on picture completion (visual attention) task ( $\mathrm{p}=0.002)$ while girls performed better on TM B (attention) and AVLT (verbal memory) tasks ( $p=0.02$ and 0.03 respectively). There was no difference 
medRxiv preprint doi: https://doi.org/10.1101/2022.02.07.22270566; this version posted February 9, 2022. The copyright holder for this preprint (which was not certified by peer review) is the author/funder, who has granted medRxiv a license to display the preprint in perpetuity. It is made available under a CC-BY-NC-ND 4.0 International license .

Yajnik \& Tan et al. Determinants of Neurocognitive Development in Children

in cognitive test scores between the offspring who were SGA compared to those born Average for Gestational Age (AGA) or between those born preterm or at term (supplementary table-1).

For conventional analysis, we present standardized beta coefficients, confidence intervals and significance level for the linear regression results for all the 8 neurocognitive development outcomes in Table $3(\mathrm{~A} \& \mathrm{~B})$. Each column represents one outcome. The corresponding BMA results are shown in Table 4. All the results are summarised in Figure $2(A \& B)$. We show results in relation to major life-course determinants.

\section{Maternal Condition During Pregnancy}

We also found some evidence that maternal condition during pregnancy was associated with child's neurocognitive outcomes. Higher maternal BMI was associated with poorer attention (lower scores on DF and DB $\beta=-0.11[95 \% \mathrm{Cl}-0.19,-0.02], \beta=$ $-0.13[95 \% \mathrm{Cl}-0.21,-0.05])$ respectively), higher physical activity scores was associated with poorer general cognitive ability (lower CPM scores $\beta=-0.13[95 \% \mathrm{Cl}-0.23,-0.03]$ ) and higher fasting insulin levels with lower performance on tasks of memory and attention (DF $\beta=-0.12[95 \% \mathrm{Cl}-0.19,-0.06]$, and $\mathrm{DB} \quad \beta=-0.1[95 \% \mathrm{Cl}-0.16,-0.03]$ ) and lower general cognitive ability (CPM $\beta=-0.1[95 \% \mathrm{Cl}-0.17,-0.03])$. We observed small effects for higher maternal folate on better visuo-spatial ability (higher BD score $\beta$ $=0.1[95 \% \mathrm{Cl} 0.01,0.18])$ and higher maternal ferritin on better attention (higher DB 
medRxiv preprint doi: https://doi.org/10.1101/2022.02.07.22270566; this version posted February 9, 2022. The copyright holder for this preprint (which was not certified by peer review) is the author/funder, who has granted medRxiv a license to display the preprint in perpetuity. It is made available under a CC-BY-NC-ND 4.0 International license .

Yajnik \& Tan et al. Determinants of Neurocognitive Development in Children

score $\beta=0.08[95 \% \mathrm{Cl} 0.01,0.16])$. Higher maternal haemoglobin was associated with poorer attention and verbal memory and higher maternal B12 with poorer general cognitive ability. The interaction term (maternal folate $X$ B12) was not significantly associated with any of the cognitive outcomes.

Nevertheless, with two exceptions, our BMA results would suggest that the above findings are not robust. The exceptions were for higher mother's fasting insulin levels being negatively associated with attention (DF scores 98.07\% PIP) and higher pre-pregnancy BMI with lower DB scores (90\% PIP).

Child's Birth Characteristics and Subsequent Development

Girls performed significantly better than boys on attention and memory (longer TM A time $\beta=-0.22[95 \% \mathrm{Cl}-0.41,-0.03]$ and $A V L T$ test $\operatorname{scores} \beta=0.30[95 \% \mathrm{Cl} 0.12$, 0.48]). Larger head circumference at birth was associated with significantly better visual attention (PC scores $\beta=0.14[95 \% \mathrm{Cl} 0.02,0.27]$ ), and higher birth weight with poorer focussed attention (TM B time $\beta=0.2[95 \% \mathrm{Cl} 0.05,0.36])$. Higher height-for-age at age 12 was associated with better global neurocognitive function (CPM scores $\beta=0.19$ $[95 \% \mathrm{Cl} 0.04,0.34]$ ), attention (DF scores $\beta=0.14[95 \% \mathrm{Cl} 0.04,0.34])$, DB scores $\beta=$ $0.15[95 \% \mathrm{Cl} 0.01,0.29])$ and visuo-spatial abilities (BD scores $\beta=0.23[95 \% \mathrm{Cl} 0.08$, 0.38]). In addition, higher fasting insulin levels at 12 years were associated with poorer visuo-spatial abilities (lower BD scores $\beta=-0.12[95 \% \mathrm{Cl}-0.22,-0.02]$ ) and higher triglyceride levels with better attention (TM A times $\beta=-0.12[95 \% \mathrm{Cl}-0.23,-0.01]$ ). 
medRxiv preprint doi: https://doi.org/10.1101/2022.02.07.22270566; this version posted February 9, 2022. The copyright holder for this preprint (which was not certified by peer review) is the author/funder, who has granted medRxiv a license to display the preprint in perpetuity. It is made available under a CC-BY-NC-ND 4.0 International license .

Yajnik \& Tan et al. Determinants of Neurocognitive Development in Children

Micronutrient concentrations in the child were also significantly associated with neurocognitive performance: Higher B12 levels with better verbal learning (AVLT scores $\beta=0.09[95 \% \mathrm{Cl} 0,0.18])$ and higher folate levels with worse general cognitive ability ( CPM scores $\beta=-0.08[95 \% \mathrm{Cl}-0.16,0])$.

BMA results suggest that only gender differences as well as the higher heightfor-age at age 12 remain robustly associated with our outcome variables BD scores (99.8\% PIP), CPM scores (92.1\% PIP) and TM B time (78.3\% PIP).

Parental education and family socioeconomic status

The most consistent finding across the set of child's neurocognitive outcomes is the positive association with parental education and their SES, especially the former. Neurocognitive performance in all the tests, with the exception of measures of attention (TM A and TM B), showed strong positive associations.

We found that parental education and SES were independently associated with global neurocognitive ability (CPM, $\beta=0.13[95 \% \mathrm{Cl} 0.03,0.23]$ and $\beta=0.1[95 \% \mathrm{Cl}$ $0.002,0.19]$ respectively). Father's education was more strongly associated with tests ofattention and working memory (DB, $\beta=0.23[95 \% \mathrm{Cl} 0.14,0.33])$ than mother's education $(\beta=0.16[95 \% \mathrm{Cl} 0.06,0.26])$. Father's education was associated with better performance on visuo-spatial abilities and memory $(\mathrm{BD} \beta=0.13[95 \% \mathrm{Cl} 0.03,0.23]$ and 
medRxiv preprint doi: https://doi.org/10.1101/2022.02.07.22270566; this version posted February 9, 2022. The copyright holder for this preprint (which was not certified by peer review) is the author/funder, who has granted medRxiv a license to display the preprint in perpetuity. It is made available under a CC-BY-NC-ND 4.0 International license .

Yajnik \& Tan et al. Determinants of Neurocognitive Development in Children

AVLT $\beta=0.11[95 \% \mathrm{Cl} 0,0.21]$ ) while mothers education correlated with higher visual attention $(P C)(\beta=0.16[95 \% \mathrm{Cl} 0.06,0.26])$.

These findings were largely affirmed to be robust by our BMA exercises. Thus, father's education was found to be a robust determinant of general cognitive ability( CPM 92.22\% PIP), visuo-spatial abilities (BD 98.5\% PIP), and attention (DB 99.99\% PIP), while mother's education for general cognitive ability (CPM 84.5\% PIP), and attention (DB 92.69\% PIP, DF 89.83\% PIP, PC 99.86\% PIP).

\section{Discussion}

Our BMA analysis supports a robust role for parental education, maternal pre pregnancy BMI and pregnancy insulin concentrations, and child's height in influencing neurocognitive outcomes in the offspring at 12 years of age. Associations of maternal nutritional status during pregnancy (folate and ferritin levels) and child's birth measurements (head circumference) were less robustly associated. These results are in line with the recent literature that suggests that parental influence and family background play a vital role in children's neurocognitive development ${ }^{40,41}$.

Parental education stood out as the most robust predictor on offspring cognitive outcome. This may influence the neurocognitive outcomes through many pathways. The effects of parental education on offspring cognition may operate through a more stimulating home environment and better opportunities for education ${ }^{41,42}$. This is supported by a two generation behavioral intervention study that showed that parental training to promote opportunities for children at school and home resulted in better school achievement and reduced behavioral problems in their offspring ${ }^{43}$. The benefits 
medRxiv preprint doi: https://doi.org/10.1101/2022.02.07.22270566; this version posted February 9, 2022. The copyright holder for this preprint (which was not certified by peer review) is the author/funder, who has granted medRxiv a license to display the preprint in perpetuity. It is made available under a CC-BY-NC-ND 4.0 International license .

Yajnik \& Tan et al. Determinants of Neurocognitive Development in Children

of such improved home environment continued into the next offspring who also showed better early child developmental functioning. The Swedish sibling adoption study demonstrates the role of socio-economic environment on neurocognitive ability in the most definitive way ${ }^{44}$. This study examined the intelligence of sibling pairs at 18 years of age, where one sibling was reared by the biological parents and the other by adoptive parents who had a higher parental education. The results showed that the adoptive sibling scored 4.41 IQ points higher than the non-adoptive sibling. Each additional unit of education of the rearing parent, was associated with a 1.94 unit increase in IQ in the offspring.

Among the early developmental factors, starting from preconception we observed that higher pre-pregnancy BMI was associated with lower cognitive scores in the offspring. Findings from developed countries show an association between maternal obesity in pregnancy and a 2 point lower $I Q$ in the offspring at age 7 years. ${ }^{45} \mathrm{~A}$ metaanalysis of 32 studies found that maternal pre-pregnancy overweight or obesity was associated with higher odds of adverse neurodevelopmental outcomes in the offspring $^{46}$. However, mothers in our study had a low BMI (average pre-pregnancy BMI 18) which makes it difficult to interpret the inverse association. One possible explanation may be related to the relatively high adiposity in Indians, ${ }^{47}$ so that the inverse association may reflect an effect of a more healthy body composition of the mother. ${ }^{48}$ Similarly, association of higher maternal fasting insulin with poor cognitive outcomes in the offspring is not easy to explain because insulin concentrations were quite low and mothers had a normal glucose tolerance. Overall, we interpret our results 
medRxiv preprint doi: https://doi.org/10.1101/2022.02.07.22270566; this version posted February 9, 2022. The copyright holder for this preprint (which was not certified by peer review) is the author/funder, who has granted medRxiv a license to display the preprint in perpetuity. It is made available under a CC-BY-NC-ND 4.0 International license .

Yajnik \& Tan et al. Determinants of Neurocognitive Development in Children

to indicate that maternal size, body composition and metabolism in pregnancy are important determinants of offspring brain development and its cognitive performance but this needs further exploration in future studies.

Micronutrients vitamins B12, folate, $C$ and D, pyridoxine and ferritin are cofactors in important celluar processes (DNA synthesis, epigenetic regulation, cell cycle regulation and energy metabolism) that impact neurodevelopment. Systematic reviews report associations between lower maternal concentrations of these micronutrients during pregnancy and enhanced risk for various adverse neurodevelopmental outcomes such as neural tube defects, autism and poorer cognitive performance in the offspring ${ }^{49,50}$. We observed only small effects for maternal folate and ferritin on visuospatial ability and attention respectively at 12 years, which were not robust under BMA. We had earlier demonstrated in a small pilot study that offspring exposed to lowest decile of maternal B12 concentrations in-utero had poorer cognitive performance at 9 years of age compared to offspring in the highest decile of maternal B12 concentrations during pregnancy. ${ }^{15}$ We did not observe such associations in the current analysis. This may suggest that the previous results were "fragile" (in the sense of Leamer $(1983)^{51}$ ) and not robust to model uncertainty. However, recently we reported findings from a randomized controlled trial performed in the same cohort. ${ }^{52}$ Pre-conceptional $\mathrm{B} 12$ supplementation improved cognitive and language outcomes in the offspring at 2-4 years of age supporting a causal role for maternal vitamin B12 status in offspring neurodevelopment. It would be interesting to see if this effect lasts at a later age.

Among birth characteristics, being born with a low birth weight is consistently associated with adverse cognitive outcomes. A meta-analysis of 35 studies on 
medRxiv preprint doi: https://doi.org/10.1101/2022.02.07.22270566; this version posted February 9, 2022. The copyright holder for this preprint (which was not certified by peer review) is the author/funder, who has granted medRxiv a license to display the preprint in perpetuity. It is made available under a CC-BY-NC-ND 4.0 International license .

Yajnik \& Tan et al. Determinants of Neurocognitive Development in Children

neurocognitive outcomes in low birth weight children showed moderate to severe deficits in attention, executive functions and academic achievement ${ }^{53}$. In another metaanalysis of 13 studies, being born with VLBW or Very Pre-Term (VPT - gestation <32 weeks) was associated with a 12 point lower IQ score in adulthood ${ }^{54}$. A prospective hospital based study, in infants born with VLBW from Pune India, found preterm children who were small for gestational age to have lower IQ scores in adulthood ${ }^{55}$. In the current study $37 \%$ of offspring were LBW, two $(0.3 \%)$ were VLBW while $10 \%$ were born preterm. There were no differences in cognitive outcomes in offspring born SGA or AGA and between those born preterm or term There were modest associations between higher birth weight and lower head circumference with poorer scores on attention tasks. However none of the birth characteristics were robust predictors under BMA.

Among the post-natal developmental influences, we found stunting to be the most consistent predictor of poorer cognitive performance. Child's height at 12 years was associated with many cognitive outcomes including generalised cognitive ability, attention and visuo-spatial ability. A metanalysis of 68 studies found a 0.22 SD increase in cognitive function score per SD increase in height for age Z scores at age 511 years ${ }^{56}$. Other child anthropometric measures were not robustly associated under BMA. 
medRxiv preprint doi: https://doi.org/10.1101/2022.02.07.22270566; this version posted February 9, 2022. The copyright holder for this preprint (which was not certified by peer review) is the author/funder, who has granted medRxiv a license to display the preprint in perpetuity. It is made available under a CC-BY-NC-ND 4.0 International license .

Yajnik \& Tan et al. Determinants of Neurocognitive Development in Children

Our BMA results generally find that only a few maternal biomarkers and initial conditions are significant, and that the most important factors determining children's neurocognitive outcomes relate to parental education and socio-economic background. The pathways for this influence may be multiple. Parental education will influence their nutrition, metabolism and behaviour in many ways from before conception, during pregnancy and continue to influence the home environment (including diet, habits, intellectual stimulation and opportunities etc) in subsequent years. The much investigated nutritional and other biological exposures appear to be embedded in parental education. Developmental biology has stressed the most prominent window for such an influence to be early in life (pre and periconceptional period, pregnancy and first two years of life) which is popularised by the term "first 1000 days". An additional consideration is the ability of educated parents to take remedial action in response to a faltering signal. All these will influence the performance of the developing nervous system $^{57-59}$.

The strength of our study is the novelty of using a BMA on life course exposure variables to identify robust predictors of cognitive outcomes in childhood. The data represented in this study traces exposures over the life course from pre-pregnancy and pregnancy to12 years of age of the offspring. These observations are unique and allow us to test the DOHaD paradigm. These longitudinal exposures encompass socioeconomic transition and impact of various Government of India schemes to improve childhood nutrition and development over the life course of these children (from 1993 to 2008). We acknowledge that the exposures will change with time. We continue to follow 
medRxiv preprint doi: https://doi.org/10.1101/2022.02.07.22270566; this version posted February 9, 2022. The copyright holder for this preprint (which was not certified by peer review) is the author/funder, who has granted medRxiv a license to display the preprint in perpetuity. It is made available under a CC-BY-NC-ND 4.0 International license .

Yajnik \& Tan et al. Determinants of Neurocognitive Development in Children

this cohort and performed neurocognitive assessments and brain imaging at 24 years of age which will allow us to examine more recent exposures and their impact on longer term cognitive outcomes into adulthood ${ }^{60}$. An additional strength of our study is that we used a comprehensive, culturally relevant measure to assess socioeconomic status of rural Indian parents. Family income alone is considered as an unreliable estimate of socioeconomic status ${ }^{61}$ and educational attainment and occupational status are known to be better indicators ${ }^{62}$. One limitation of our study is that, because of unavailability of data, we were not able to specifically assess family home environment and parent child interactions which are known to moderate associations of SES with child neurocognitive performance. Finally, being an observational, non-randomized study we cannot be certain about the causality of associations.

\section{Conclusion}

In this paper, we investigated the linkages that life course exposures to various biological and socio-economic factors have on neurocognitive performance at age 12 using data from the Pune Maternal Nutrition Study (PMNS). The exposures included socioeconomic background as well as a range of biometric measures for the mother and the child, from birth until the time at which the neurocognitive tests were taken. In our analysis, we explicitly account for the important issue of model uncertainty in regression exercises by exploiting the BMA methodology.

Across the measures of neurocognitive abilities, once we account for model uncertainty, we generally find overwhelming importance for the role of parental 
medRxiv preprint doi: https://doi.org/10.1101/2022.02.07.22270566; this version posted February 9, 2022. The copyright holder for this preprint (which was not certified by peer review) is the author/funder, who has granted medRxiv a license to display the preprint in perpetuity. It is made available under a CC-BY-NC-ND 4.0 International license .

Yajnik \& Tan et al. Determinants of Neurocognitive Development in Children

education in determining a child's outcomes at age 12. The associations with child's height indicate that remedial interventions in the post-natal life may have important and significant associations with neurocognitive development. Though nutritional deficiencies in-utero or size at birth have long-term influence, those effects are potentially reversed by post-birth remediation. Coupled with the success of our vitamin B12 intervention trial, current results inform public health policy in India to consider social interventions in children born into families with low socio-economic status to improve human capital, over and above the already operational nutritional programs.

Table 1: Maternal and paternal characteristics during pregnancy (1994-1996) and child characteristics at 12 years $(2006-2008)$

Table 2: Neurocognitive performance scores in the children at 12 years

Table 3A - Results of Linear Regression analysis between parental exposures and offspring neurocognitive scores at age 12

Table 3B - Results of Linear Regression analysis between childhood variables and offspring neurocognitive scores at age 12

Table -4 Results of Bayesian analysis

Figure 1: Time lines in the PMNS cohort and participant recruitment

Figure 2: (A) Represents linear regression beta coefficients for associations between life-course variables and 12 year neurocognitive scores in the offspring. Figure $(B)$ represents Bayesian Model Averaging (BMA) Posterior Inclusion Probability (PIP) \% for robust predictors. 
medRxiv preprint doi: https://doi.org/10.1101/2022.02.07.22270566; this version posted February 9, 2022. The copyright holder for this preprint (which was not certified by peer review) is the author/funder, who has granted medRxiv a license to display the preprint in perpetuity. It is made available under a CC-BY-NC-ND 4.0 International license .

Yajnik \& Tan et al. Determinants of Neurocognitive Development in Children

Acknowledgement: The authors thank Mrs. Aboli Bhalerao for her help with data management and statistical analysis.

Funding: Tan thanks the Greg and Cindy Page Faculty Distribution Fund for financial support. The follow up of the PMNS is supported by the Wellcome Trust, the Medical Research Council, UK and the Dept of Biotechnology, Government of India. RVB is supported by DBT Wellcome India Alliance Intermediate Fellowship (IA/CPHI/1/6/1502665).

Conflict of Interest: None declared

\section{References}

1. Jolly R. Early childhood development: the global challenge. Lancet. 2007;369.

2. Grantham-McGregor S, Cheung YB, Cueto S, Glewwe P, Richter L, Strupp B.

Developmental potential in the first 5 years for children in developing countries.

Lancet. 2007;369(9555):60-70. doi:10.1016/S0140-6736(07)60032-4

3. Walker SP, Wachs TD, Meeks Gardner J, et al. Child development: risk factors for adverse outcomes in developing countries. Lancet. 2007;369(9556):145-157.

doi:10.1016/S0140-6736(07)60076-2

4. Neelsen S, Stratmann T. Effects of prenatal and early life malnutrition: Evidence from the Greek famine. J Health Econ. 2011;30(3):479-488.

doi:10.1016/j.jhealeco.2011.03.001

5. Stein Z, Susser M, Saenger G, Marolla F. Nutrition and mental performance. 
medRxiv preprint doi: https://doi.org/10.1101/2022.02.07.22270566; this version posted February 9, 2022. The copyright holder for this preprint (which was not certified by peer review) is the author/funder, who has granted medRxiv a license to display the preprint in perpetuity. It is made available under a CC-BY-NC-ND 4.0 International license .

Yajnik \& Tan et al. Determinants of Neurocognitive Development in Children

Science (80- ). 1972;178(4062):708-713. doi:10.1126/science.178.4062.708

6. Chen Y, Zhou LA. The long-term health and economic consequences of the 19591961 famine in China. J Health Econ. 2007;26(4):659-681.

doi:10.1016/j.jhealeco.2006.12.006

7. Ampaabeng SK, Tan CM. The long-term cognitive consequences of early childhood malnutrition: The case of famine in Ghana. J Health Econ.

2013;32(6):1013-1027. doi:10.1016/j.jhealeco.2013.08.001

8. Yamamoto JM, Benham JL, Deborah Dewey J, et al. Neurocognitive and behavioural outcomes in offspring exposed to maternal pre-existing diabetes: a systematic review and meta-analysis. Diabetologia. 2019;62:1561-1574.

9. Almond D, Edlund L, Li H, Zhang J. Long-Term Effects of Early-Life Development:

Evidence from the 1959 to 1961 China Famine. NBER Chapters. Published online 2010:321-345. Accessed October 1, 2020.

https://ideas.repec.org/h/nbr/nberch/8166.html

10. Veena SR, Krishnaveni G V., Srinivasan K, et al. Higher maternal plasma folate but not vitamin B-12 concentrations during pregnancy are associated with better cognitive function scores in 9- to 10- year-old children in South India. J Nutr. 2010;140(5):1014-1022. doi:10.3945/jn.109.118075

11. Godbole K, Deshmukh U, Yajnik C. Nutri-genetic determinants of neural tube defects in India. Indian Pediatr. 2009;46(6):467-475. Accessed October 1, 2020. https://europepmc.org/article/med/19556657

12. Schmidt RJ, Tancredi DJ, Ozonoff S, et al. Maternal periconceptional folic acid intake and risk of autism spectrum disorders and developmental delay in the 
medRxiv preprint doi: https://doi.org/10.1101/2022.02.07.22270566; this version posted February 9, 2022. The copyright holder for this preprint (which was not certified by peer review) is the author/funder, who has granted medRxiv a license to display the preprint in perpetuity. It is made available under a CC-BY-NC-ND 4.0 International license .

Yajnik \& Tan et al. Determinants of Neurocognitive Development in Children

CHARGE (CHildhood Autism Risks from Genetics and Environment) case-control study. Am J Clin Nutr. 2012;96(1):80-89. doi:10.3945/ajcn.110.004416

13. Chaudhari S, Otiv M, Chitale A, Pandit A, Hoge M. Pune Low Birth Weight Study Cognitive Abilities and Educational Performance at Twelve Years. Indian Pediatr. 2004;41(2):121-128. Accessed October 1, 2020. https://europepmc.org/article/med/15004297

14. Bhate VK, Joshi SM, Ladkat RS, et al. Vitamin B12 and folate during pregnancy and offspring motor, mental and social development at 2 years of age. J Dev Orig Health Dis. 2012;3(2):123-130. doi:10.1017/S2040174411000778

15. Bhate V, Deshpande S, Bhat D, et al. Vitamin B12 status of pregnant Indian women and cognitive function in their 9-year-old children. Food Nutr Bull. 2008;29(4):249-254. doi:10.1177/156482650802900401

16. Bommer C, Vollmer S, Subramanian S V. How socioeconomic status moderates the stunting-age relationship in low-income and middle-income countries. BMJ Glob Heal. 2019;4(1):1175. doi:10.1136/bmjgh-2018-001175

17. Behrman JR, Schott W, Duc LT, et al. Intergenerational transmission of poverty and inequality: Parental resources and schooling attainment and Children's Human Capital in Ethiopia, India, Peru, and Vietnam. Econ Dev Cult Change. 2017;65(4):657-697. doi:10.1086/691971

18. Cesar G Victora, Linda Adair, Caroline Fall, Pedro C Hallal, Reynaldo Martorell, Linda Richter, Harshpal Singh Sachdev M and CUSG. Maternal and child undernutrition: consequences for adult health and human capital. Lancet. 2008;371(9609):340-357. doi:10.1016/S0140-6736(07)61692-4 
medRxiv preprint doi: https://doi.org/10.1101/2022.02.07.22270566; this version posted February 9, 2022. The copyright holder for this preprint (which was not certified by peer review) is the author/funder, who has granted medRxiv a license to display the preprint in perpetuity. It is made available under a CC-BY-NC-ND 4.0 International license .

Yajnik \& Tan et al. Determinants of Neurocognitive Development in Children

19. Raftery AE, Madigan D, Hoeting JA. Bayesian Model Averaging for Linear Regression Models. J Am Stat Assoc. 1997;92(437):179-191.

doi:10.1080/01621459.1997.10473615

20. Raftery AE, Zheng Y. Discussion: Performance of Bayesian Model Averaging. $J$ Am Stat Assoc. 2003;98(464):931-938.

21. Madigan D, Raftery AE. Model Selection and Accounting for Model Uncertainty in Graphical Models Using Occam's Window. J Am Stat Assoc. 1994;89:1335-1346.

22. Yajnik CS, Katre PA, Joshi SM, et al. Higher glucose, insulin and insulin resistance (HOMA-IR) in childhood predict adverse cardiovascular risk in early adulthood: the Pune Children's Study. Diabetologia. 2015;58(7):1626-1636.

doi:10.1007/s00125-015-3602-z

23. Yajnik CS, Deshpande SS, Jackson AA, et al. Vitamin B12 and folate concentrations during pregnancy and insulin resistance in the offspring: the Pune Maternal Nutrition Study. Diabetologia. 2008;51(1):29-38. doi:10.1007/s00125007-0793-y

24. Rao S, Yajnik CS, Kanade A, et al. Intake of Micronutrient-Rich Foods in Rural Indian Mothers Is Associated with the Size of Their Babies at Birth: Pune Maternal Nutrition Study. J Nutr. 2001;131(4):1217-1224.

doi:https://doi.org/10.1093/jn/131.4.1217

25. Kanade A, Rao S, Yajnik C, Margetts B, Fall C. Rapid Assessment of Maternal Activity among Rural Indian Mothers (Pune Maternal Nutrition Study). Public Health Nutr. 2005;8(6):588-595.

26. International Statistical Classification of Diseases and Related Health Problems, 
medRxiv preprint doi: https://doi.org/10.1101/2022.02.07.22270566; this version posted February 9, 2022. The copyright holder for this preprint (which was not certified by peer review) is the author/funder, who has granted medRxiv a license to display the preprint in perpetuity. It is made available under a CC-BY-NC-ND 4.0 International license .

Yajnik \& Tan et al. Determinants of Neurocognitive Development in Children

Tenth Revision. 2nd ed. World Health Organization; 2004.

27. Onis M de, Habicht JP. Anthropometric reference data for international use:

recommendations from a World Health Organization Expert Committee. Am J Clin

Nutr. 1996;64(4):650-658.

28. Onis M de, Onyango A, Borghi E, et al. Worldwide implementation of the WHO

Child Growth Standards. Public Health Nutr. 2012;15(9):1603-1610.

doi:10.1017/S136898001200105X

29. Yajnik CS, Bandopadhyay S, Bhalerao A, et al. Poor In Utero Growth, and

Reduced $\beta$-Cell Compensation and High Fasting Glucose From Childhood, Are

Harbingers of Glucose Intolerance in Young Indians. Diabetes Care.

2021;44(12):2747-2757.

30. Parikh, U; Trivedi G. Manual of Socio-Economic Status Scale (Rural).

Manasayan; 1964.

31. Manual MA. Malin's Intelligence Scale for Indian Children (Indian Adaptation of

WISC). Indian Psychological Corporation; 1969.

32. Kar BR, Rao SL, Chandramouli BA, Thennarasu K. NIMHANS

Neuropsychological Battery for Children: Manual.; 2004.

33. Raven J. Manual for the Raven's Progressive Matrices and Vocabulary Scales.

Lewis; 1979.

34. D’Elia LF, Satz P, Uchiyama C, White T. Color Trails Test Professional Manual. Psychol Assess Resour. Published online 1996.

35. Villar J, Ismail LC, Victora CG, et al. International standards for newborn weight, length, and head circumference by gestational age and sex: the Newborn Cross- 
medRxiv preprint doi: https://doi.org/10.1101/2022.02.07.22270566; this version posted February 9, 2022. The copyright holder for this preprint (which was not certified by peer review) is the author/funder, who has granted medRxiv a license to display the preprint in perpetuity. It is made available under a CC-BY-NC-ND 4.0 International license .

Yajnik \& Tan et al. Determinants of Neurocognitive Development in Children

Sectional Study of the INTERGROWTH-21st Project. Lancet.

2014;384(9946):857-868.

36. Onis M de, Onyango AW, Borghi E, Siyam A, Nishida C, Siekmann J.

Development of a WHO growth reference for school-aged children and adolescents. Bull World Health Organ. 2007;85(9):660-667.

37. Eicher T, Helfman L, Lenkoski A. Robust FDI determinants: Bayesian Model Averaging in the presence of selection bias. J Macroecon. 2012;34(3):637-651 . https://econpapers.repec.org/RePEc:eee:jmacro:v:34:y:2012:i:3:p:637-651

38. Kass RE, Raftery AE. Bayes factors. J Am Stat Assoc. 1995;90(430):773-795. doi:10.1080/01621459.1995.10476572

39. Durlauf SN, Kourtellos A, Tan CM. Are any growth theories robust? In: Economic Journal. Vol 118. John Wiley \& Sons, Ltd; 2008:329-346. doi:10.1111/j.14680297.2007.02123.x

40. Cunha F, Heckman JJ. Formulating, Identifying, and Estimating the Technology of Cognitive and Noncognitive Skill Formation. J Hum Resour. 2008;43(4):738-782.

41. Feinstein L. Inequality in the early cognitive development of British children in the 1970 cohort. Economica. 2003;70(277):73-97. doi:10.1111/1468-0335.t01-100272

42. Ursache A, Noble KG. Socioeconomic status, white matter, and executive function in children. Brain Behav. 2016;6(10). doi:10.1002/brb3.531

43. Hill KG, Bailey JA, Steeger CM, et al. Outcomes of childhood preventive intervention across 2 generations: A nonrandomized controlled trial. JAMA Pediatr. 2020;174(8):764-771. doi:10.1001/jamapediatrics.2020.1310 
medRxiv preprint doi: https://doi.org/10.1101/2022.02.07.22270566; this version posted February 9, 2022. The copyright holder for this preprint (which was not certified by peer review) is the author/funder, who has granted medRxiv a license to display the preprint in perpetuity. It is made available under a CC-BY-NC-ND 4.0 International license .

Yajnik \& Tan et al. Determinants of Neurocognitive Development in Children

44. Kendler KS, EricTurkheimer, Ohlsson H, Sundquist J, Sundquist K. Family environment and the malleability of cognitive ability a Swedish national homereared and adopted-away cosibling control study. Proc Natl Acad Sci U S A. 2015;112(15):4612-4617. doi:10.1073/pnas.1417106112

45. Huang L, Yu X, Keim S, Li L, Zhang L, Zhang J. Maternal prepregnancy obesity and child neurodevelopment in the Collaborative Perinatal Project. Int $J$ Epidemiol. 2014;43(3):783-792.

46. Sanchez CE, Barry C, Sabhlok A, et al. Maternal pre-pregnancy obesity and child neurodevelopmental outcomes: a meta-analysis. Obes Rev. 2018;19(4).

47. Yajnik CS. The lifecycle effects of nutrition and body size on adult adiposity, diabetes and cardiovascular disease. Obes Rev. 2002;3(3). doi:10.1046/j.1467789x.2002.00072.x

48. Neggers YH, Goldenberg RL, Ramey SL, Cliver SP. Maternal prepregnancy body mass index and psychomotor development in children, Acta Obstetricia et Gynecologica Scandinavica. Acta Obstet Gynecol Scand. 2003;82(3):235-240.

49. Veena SR, Gale CR, Krishnaveni G V, Kehoe SH, Srinivasan K, Fall CH. Association between maternal nutritional status in pregnancy and offspring cognitive function during childhood and adolescence; a systematic review. BMC Pregnancy Childbirth. 2016;16(220):1-24. doi:10.1186/s12884-016-1011-z

50. Behere R V., Deshmukh AS, Otiv S, Gupte MD, Yajnik CS. Maternal Vitamin B12 Status During Pregnancy and Its Association With Outcomes of Pregnancy and Health of the Offspring: A Systematic Review and Implications for Policy in India. Frontiers in endocrinology. Front Endocrinol (Lausanne). 2021;12. 
medRxiv preprint doi: https://doi.org/10.1101/2022.02.07.22270566; this version posted February 9, 2022. The copyright holder for this preprint (which was not certified by peer review) is the author/funder, who has granted medRxiv a license to display the preprint in perpetuity. It is made available under a CC-BY-NC-ND 4.0 International license .

Yajnik \& Tan et al. Determinants of Neurocognitive Development in Children

51. Leamer EE. Let's Take the Con Out of Econometrics. Am Econ Rev. 1983;73(1).

52. D’souza N, Behere R V., Patni B, et al. Pre-conceptional Maternal Vitamin B12 Supplementation Improves Offspring Neurodevelopment at 2 Years of Age:

PRIYA Trial. Front Pediatr. Published online 2021. doi:10.3389/fped.2021.755977

53. Aarnoudse-Moens CSH, Weisglas-Kuperus N, Goudoever JB van, Oosterlaan J. Meta-analysis of neurobehavioral outcomes in very preterm and/or very low birth weight children. Pediatrics. 2009;124(2).

54. Robert Eves, Mendonça M, Baumann N, et al. Association of Very Preterm Birth or Very Low Birth Weight With Intelligence in Adulthood: An Individual Participant Data Meta-analysis. JAMA Pediatr. 2021;175(8).

55. Chaudhari S, Otiv M, Khairnar B, Pandit A, Hoge M, Sayyad M. Pune low birth weight study - birth to adulthood - cognitive development. Indian Pediatr. 2013;50:853-857.

56. Sudfeld CR, McCoy DC, Danaei G, et al. Linear growth and child development in low- and middle-income countries: a meta-analysis. Pediatrics. 2015;135(5).

57. Walhovd KB, Krogsrud SK, Amlien IK, et al. Neurodevelopmental origins of lifespan changes in brain and cognition. Proc Natl Acad Sci U S A. 2016;113(33):9357-9362. doi:10.1073/pnas.1524259113

58. Ozernov-Palchik O, Norton ES, Wang Y, et al. The relationship between socioeconomic status and white matter microstructure in pre-reading children: A longitudinal investigation. Hum Brain Mapp. 2019;40(3):741-754.

doi:10.1002/hbm.24407

59. Vanderauwera J, van Setten ERH, Maurits NM, Maassen BAM. The interplay of 
medRxiv preprint doi: https://doi.org/10.1101/2022.02.07.22270566; this version posted February 9, 2022. The copyright holder for this preprint (which was not certified by peer review) is the author/funder, who has granted medRxiv a license to display the preprint in perpetuity.

It is made available under a CC-BY-NC-ND 4.0 International license .

Yajnik \& Tan et al. Determinants of Neurocognitive Development in Children

socio-economic status represented by paternal educational level, white matter structure and reading. PLoS One. 2019;14(5). doi:10.1371/journal.pone.0215560

60. Behere R V, Deshpande G, Bandyopadhyay SK, Yajnik C. Maternal vitamin B12, folate during pregnancy and neurocognitive outcomes in young adults of the Pune Maternal Nutrition Study (PMNS) prospective birth cohort: study protocol. BMJ Open. 2021;11(9).

61. Violato M, Petrou S, Gray R, Redshaw M. Family income and child cognitive and behavioural development in the United Kingdom: Does money matter? Health Econ. 2011;20(10):1201-1225. doi:10.1002/hec.1665

62. Farah MJ. The Neuroscience of Socioeconomic Status: Correlates, Causes, and Consequences. Published online 2017. doi:10.1016/j.neuron.2017.08.034

Table 1: Maternal and paternal characteristics during pregnancy (1994-1996) and child characteristics at 12 years (2006-2008)

\begin{tabular}{|c|c|c|c|}
\hline Variables & N & Mean & Std. Deviation \\
\hline Maternal & & & \\
\hline Age in years & 686 & 21.36 & 3.51 \\
\hline Education in years & 664 & 5.73 & 3.93 \\
\hline Pre pregnancy BMI (kg/m2) & 680 & 18.03 & 1.88 \\
\hline Activity score & 684 & 69.92 & 23.11 \\
\hline Total calorie intake & 684 & 1723.21 & 410.72 \\
\hline Hb (gm\%) & 678 & 11.11 & 1.72 \\
\hline Fasting glucose (mg/dl) & 678 & 71.33 & 10.39 \\
\hline Fasting insulin (pmol/L) & 675 & 46.08 & 339.61 \\
\hline Cholesterol (mg/dl) & 678 & 169.96 & 33.32 \\
\hline Triglycerides (mg/dl) & 678 & 113.2 & 33.5 \\
\hline Vitamin B12 (pmol/L) & 674 & 145.24 & 66.99 \\
\hline Folate $(\mathrm{nmol} / \mathrm{L})$ & 674 & 19.54 & 18.34 \\
\hline Homocysteine (mmol/L) & 674 & 8.91 & 2.82 \\
\hline
\end{tabular}


medRxiv preprint doi: https://doi.org/10.1101/2022.02.07.22270566; this version posted February 9, 2022. The copyright holder for this preprint (which was not certified by peer review) is the author/funder, who has granted medRxiv a license to display the preprint in perpetuity.

It is made available under a CC-BY-NC-ND 4.0 International license .

Yajnik \& Tan et al. Determinants of Neurocognitive Development in Children

\begin{tabular}{|c|c|c|c|}
\hline Vitamin C (micromol/L) & 678 & 16.84 & 20.0 \\
\hline Ferritin $(\mathrm{mcg} / \mathrm{L})$ & 678 & 15.8 & 14.59 \\
\hline \multicolumn{4}{|l|}{ Paternal } \\
\hline Socio-economic status & 685 & 26.92 & 6.55 \\
\hline education & 664 & 7.84 & 3.93 \\
\hline BMI & 652 & 19.44 & 2.54 \\
\hline \multicolumn{4}{|l|}{ Birth } \\
\hline Birth Wt for age Z score ${ }^{*}$ & 610 & -1.56 & 0.93 \\
\hline Birth Ht for age Z score ${ }^{*}$ & 627 & -1.08 & 1.17 \\
\hline Head circumference (cms) & 674 & 32.91 & 1.43 \\
\hline \multicolumn{4}{|l|}{ Child at 12 years } \\
\hline Education in years & 681 & 5.88 & 1.28 \\
\hline Ht for Age Z score & 686 & -1.19 & 0.92 \\
\hline BMI for Age Z score & 686 & -1.71 & 1.18 \\
\hline Head Circumference (cms) & 686 & 50.95 & 4.7 \\
\hline $\mathrm{Hb}(\mathrm{gm} \%)$ & 686 & 12.78 & 1.32 \\
\hline Glucose $(\mathrm{mg} / \mathrm{dl})$ & 683 & 87.02 & 7.14 \\
\hline Fasting Insulin (pmol/L) & 687 & 5.79 & 3.29 \\
\hline Cholesterol (mg/dl) & 686 & 130.95 & 23.84 \\
\hline Triglycerides(mg/dl) & 686 & 58.63 & 22.12 \\
\hline Vitamin B12 (pmol/L) & 681 & 207.89 & 87.58 \\
\hline Folate (nmol/L) & 681 & 24.31 & 11.0 \\
\hline Homocysteine (mmol/L) & 679 & 13.33 & 6.92 \\
\hline Ferritin $(\mathrm{mcg} / \mathrm{L})$ & 652 & 22.09 & 15.02 \\
\hline
\end{tabular}

*Height and weight for age $\mathrm{Z}$ scores at birth calculated using the INTERGROWTH criteria \#Height and BMI for age Z scores at 12 years calculated according to WHO 2007 reference criteria.

Table 2: Neurocognitive performance scores in the children at 12 years

\begin{tabular}{|l|c|c|c|c|c|}
\hline Cognitive test & $\begin{array}{c}\text { Mean } \\
\text { [Boys- 357] }\end{array}$ & S.D. & $\begin{array}{c}\text { Mean } \\
\text { [Girls- } \\
\text { 329] }\end{array}$ & S.D. & $\begin{array}{c}\text { P } \\
\text { value }\end{array}$ \\
\hline & & & & & \\
\hline
\end{tabular}


medRxiv preprint doi: https://doi.org/10.1101/2022.02.07.22270566; this version posted February 9, 2022. The copyright holder for this preprint (which was not certified by peer review) is the author/funder, who has granted medRxiv a license to display the preprint in perpetuity.

\section{It is made available under a CC-BY-NC-ND 4.0 International license .}

Yajnik \& Tan et al. Determinants of Neurocognitive Development in Children

\begin{tabular}{|c|c|c|c|c|c|}
\hline Color Progressive Matrices & 28.5 & 7.4 & 27.5 & 7.2 & 0.07 \\
\hline Picture Completion & 10.3 & 3.3 & 9.5 & 3.4 & $\mathbf{0 . 0 0 2}^{\boldsymbol{*}}$ \\
\hline Digit span forward & 4.9 & 1.3 & 4.9 & 1.3 & 0.9 \\
\hline Digit span backward & 3.3 & 1.1 & 3.3 & 1.0 & 0.9 \\
\hline Color Trail making test A (time taken in secs) & 79.9 & 37.1 & 74.1 & 26.1 & $\mathbf{0 . 0 2}^{\boldsymbol{*}}$ \\
\hline Color Trail making test B (time taken in secs) & 174.2 & 65.0 & 177.1 & 61.3 & 0.6 \\
\hline $\begin{array}{c}\text { Auditory verbal learning test } \\
\text { (total learning score) }\end{array}$ & 47.6 & 10.1 & 49.3 & 10.0 & $\mathbf{0 . 0 3}^{\boldsymbol{*}}$ \\
\hline Block design (total correct score) & 16.4 & 10.2 & 15.1 & 10.2 & 0.08 \\
\hline
\end{tabular}

*Significance at $\mathrm{P}<0.05$ 
Table 3A - Results of Linear Regression analysis between parental exposures and offspring neurocognitive scores at age 12

\begin{tabular}{|c|c|c|c|c|c|c|c|c|}
\hline $\begin{array}{l}\text { Parental } \\
\text { Exposures }\end{array}$ & $\begin{array}{l}\text { Color } \\
\text { Progressive } \\
\text { Matrices } \\
\end{array}$ & $\begin{array}{l}\text { Picture } \\
\text { Completion }\end{array}$ & $\begin{array}{l}\text { Digit span } \\
\text { forward }\end{array}$ & $\begin{array}{l}\text { Digit span } \\
\text { backward }\end{array}$ & $\begin{array}{l}\text { Color Trail } \\
\text { making test A } \\
\text { (time taken }\end{array}$ & $\begin{array}{l}\text { Color Trail } \\
\text { making test B } \\
\text { (time taken }\end{array}$ & $\begin{array}{l}\text { Auditory verbal } \\
\text { learning test }\end{array}$ & $\begin{array}{l}\text { Block design } \\
\text { (total correct } \\
\text { score) } \\
\end{array}$ \\
\hline \multicolumn{9}{|l|}{$\begin{array}{l}\text { Maternal } \\
\text { variables } \\
\text { during } \\
\text { pregnancy \# }\end{array}$} \\
\hline Age & $0.07[-0.02,0.15]$ & $0.05[-0.03,0.14]$ & $-0.01[-0.1,0.07]$ & $0.0001[-0.08,0.08]$ & $0.01[-0.08,0.11]$ & $-0.07[-0.16,0.02]$ & $0.04[-0.05,0.13]$ & $0.09[0,0.17]$ \\
\hline Education & $0.14[0.04,0.23]^{* *}$ & $0.16[0.06,0.26]^{* *}$ & $0.09[-0.01,0.19]$ & $0.16[0.06,0.26]^{* *}$ & $-0.04[-0.15,0.07]$ & $-0.08[-0.19,0.02]$ & $0.07[-0.03,0.18]$ & $0.05[-0.05,0.15]$ \\
\hline $\begin{array}{l}\text { Pre } \\
\text { pregnancy } \\
\text { BMI }\end{array}$ & $-0.08[-0.16,0.01]$ & $-0.07[-0.16,0.01]$ & $-0.11[-0.19,-0.02]^{*}$ & $-0.13[-0.21,0.05]^{* *}$ & $-0.01[-0.11,0.08]$ & $0.06[-0.03,0.15]$ & $-0.05[-0.13,0.04]$ & $-0.08[-0.16,0.01]$ \\
\hline Activity score & $-0.13[-0.23,-0.03]^{* *}$ & $-0.07[-0.16,0.03]$ & $-0.06[-0.16,0.04]$ & $0.01[-0.08,0.11]$ & $0.07[-0.03,0.18]$ & $0.06[-0.04,0.16]$ & $0.002[-0.1,0.1]$ & $-0.12[-0.21,-0.02]^{*}$ \\
\hline Calorie intake & $-0.07[-0.15,0.01]$ & $0.0001[-0.08,0.08]$ & $0.04[-0.04,0.13]$ & $0.07[-0.01,0.15]$ & $0.06[-0.03,0.15]$ & $-0.04[-0.13,0.05]$ & $0.05[-0.04,0.13]$ & $0.001[-0.09,0.08]$ \\
\hline Haemoglobin & $-0.07[-0.15,0.02]$ & $-0.03[-0.12,0.06]$ & $0.05[-0.04,0.13]$ & $-0.14[-0.22,-0.05] * *$ & $0.1[0.01,0.2]^{*}$ & $0.1[0.01,0.19]^{*}$ & $-0.09[-0.18,0] *$ & $-0.03[-0.12,0.05]$ \\
\hline Fasting glucose & $-0.01[-0.1,0.07]$ & $0.01[-0.08,0.09]$ & $-0.0001[-0.09,0.09]$ & $0.002[-0.08,0.09]$ & $0.08[-0.02,0.17]$ & $0.05[-0.04,0.14]$ & $-0.04[-0.13,0.05]$ & $-0.02[-0.11,0.06]$ \\
\hline Fasting insulin & $-0.1[-0.17,-0.03]^{* * *}$ & $-0.05[-0.12,0.02]$ & $-0.12[-0.19,-0.06]^{* * * *}$ & $-0.1[-0.16,-0.03]^{* *}$ & $-0.04[-0.12,0.03]$ & $-0.08[-0.15,004]^{*}$ & $-0.06[-0.13,0.01]$ & $-0.05[-0.12,0.02]$ \\
\hline Cholesterol & $-0.01[-0.09,0.1]$ & $0.01[-0.09,0.11]$ & $0.02[-0.08,0.12]$ & $0.02[-0.08,0.11]$ & $-0.06[-0.16,0.05]$ & $-0.03[-0.14,0.07]$ & $-0.04[-0.15,0.06]$ & $-0.04[-0.14,0.06]$ \\
\hline Triglycerides & $-0.04[-0.13,0.05]$ & $-0.06[-0.15,0.04]$ & $-0.02[-0.12,0.07]$ & $-0.06[-0.15,0.02]$ & $0.09[-0.01,0.19]$ & $0.03[-0.07,0.13]$ & $-0.03[-0.12,0.07]$ & $0.01[-0.08,0.11]$ \\
\hline Vitamin B12 & $-0.11[-0.19,-0.02] *$ & $-0.04[-0.13,0.05]$ & $0.003[-0.09,0.09]$ & $0.06[-0.02,0.15]$ & $-0.04[-0.14,0.06]$ & $-0.07[-0.17,0.02]$ & $0.01[-0.08,0.1]$ & $-0.09[-0.18,0] *$ \\
\hline Serum folate & $0.06[-0.02,0.15]$ & $0.03[-0.05,0.12]$ & $0.03[-0.06,0.12]$ & $0.02[-0.06,0.11]$ & $-0.08[-0.17,0.01]$ & $-0.03[-0.12,0.06]$ & $0.01[-0.08,0.1]$ & $0.1[0.01,0.18]^{*}$ \\
\hline Homocysteine & $-0.06[-0.15,0.03]$ & $-0.03[-0.12,0.06]$ & $0.04[-0.05,0.13]$ & $0.04[-0.05,0.12]$ & $0.06[-0.04,0.16]$ & $0.06[-0.04,0.15]$ & $-0.01[-0.1,0.09]$ & $-0.02[-0.11,0.07]$ \\
\hline Vitamin C & $0.04[-0.04,0.12]$ & $0.04[-0.04,0.12]$ & $0.04[-0.04,0.12]$ & $0.02[-0.06,0.1]$ & $-0.02[-0.11,0.07]$ & $0.04[-0.04,0.13]$ & $0.02[-0.06,0.11]$ & $0.05[-0.03,0.14]$ \\
\hline Ferritin & $0.05[-0.03,0.13]$ & $-0.02[-0.1,0.07]$ & $0.002[-0.08,0.08]$ & $0.08[0.01,0.16]^{*}$ & $0.02[-0.07,0.11]$ & $0.001[-0.08,0.09]$ & $0.06[-0.02,0.14]$ & $0.06[-0.03,0.14]$ \\
\hline $\begin{array}{l}\text { Interaction term } \\
\text { (B12* folate) }\end{array}$ & $0.004[-0.05,0.06]$ & $0.01[-0.04,0.06]$ & $0.04[-0.02,0.09]$ & $0.01[-0.04,0.06]$ & $0.02[-0.04,0.08]$ & $0.02[-0.04,0.07]$ & $0.04[-0.01,0.1]$ & $0.01[-0.04,0.07]$ \\
\hline \multicolumn{9}{|l|}{$\begin{array}{l}\text { Paternal } \\
\text { variables }\end{array}$} \\
\hline Father's age & $0.01[-0.07,0.09]$ & $0.05[-0.03,0.13]$ & $0.03[-0.05,0.11]$ & $0.01[-0.07,0.09]$ & $0.06[-0.02,0.15]$ & $0.0002[-0.08,0.08]$ & $0.04[-0.04,0.12]$ & $-0.02[-0.1,0.06]$ \\
\hline $\begin{array}{l}\text { Father's } \\
\text { education }\end{array}$ & $0.13[0.03,0.23]^{* *}$ & $-0.02[-0.12,0.08]$ & $0.03[-0.07,0.13]$ & $0.23[0.14,0.33]^{* * *}$ & $-0.05[-0.16,0.05]$ & $-0.06[-0.16,0.04]$ & $0.11[0,0.21]^{*}$ & $0.13[0.03,0.23]^{*}$ \\
\hline Father's BMI & $0.02[-0.06,0.1]$ & $0.05[-0.04,0.13]$ & $0.07[-0.01,0.16]$ & $0.12[0.04,0.2]^{* *}$ & $0.02[-0.07,0.11]$ & $-0.07[-0.16,0.02]$ & $-0.03[-0.12,0.06]$ & $0.02[-0.06,0.1]$ \\
\hline $\begin{array}{l}\text { Socio economic } \\
\text { score }\end{array}$ & $0.1[0.002,0.19]^{*}$ & $0.08[-0.02,0.17]$ & $0.03[-0.07,0.12]$ & $0[-0.09,0.09]$ & $-0.07[-0.17,0.04]$ & $-0.01[-0.11,0.09]$ & $-0.01[-0.11,0.08]$ & $0.08[-0.02,0.17]$ \\
\hline
\end{tabular}


Table 3B - Results of Linear Regression analysis between childhood variables and offspring neurocognitive scores at age 12

\begin{tabular}{|c|c|c|c|c|c|c|c|c|}
\hline $\begin{array}{l}\text { Parental } \\
\text { Exposures }\end{array}$ & $\begin{array}{l}\text { Color } \\
\text { Progressive } \\
\text { Matrices } \\
\end{array}$ & $\begin{array}{l}\text { Picture } \\
\text { Completion }\end{array}$ & $\begin{array}{l}\text { Digit span } \\
\text { forward }\end{array}$ & $\begin{array}{l}\text { Digit span } \\
\text { backward }\end{array}$ & $\begin{array}{l}\text { Color Trail } \\
\text { making test A } \\
\text { (time taken }\end{array}$ & $\begin{array}{l}\text { Color Trail } \\
\text { making test B } \\
\text { (time taken }\end{array}$ & $\begin{array}{l}\text { Auditory } \\
\text { verbal } \\
\text { learning test }\end{array}$ & $\begin{array}{l}\text { Block design } \\
\text { (total correct } \\
\text { score) }\end{array}$ \\
\hline \multicolumn{9}{|l|}{$\begin{array}{l}\text { Child } \\
\text { variables at } \\
\text { birth }\end{array}$} \\
\hline Gender & $0.01[-0.16,0.18]$ & $-0.1[-0.27,0.08]$ & $0.07[-0.11,0.24]$ & $0.11[-0.06,0.28]$ & $-0.22[-0.41,-0.03]^{*}$ & $-0.01[-0.19,0.17]$ & $0.3[0.12,0.48]^{* *}$ & $-0.02[-0.2,0.16]$ \\
\hline $\begin{array}{l}\text { Head } \\
\text { circumference }\end{array}$ & $-0.02[-0.14,0.1]$ & $0.14[0.02,0.27]^{*}$ & $0.11[-0.02,0.24]$ & $0.08[-0.05,0.2]$ & $-0.11[-0.24,0.03]$ & $-0.05[-0.18,0.08]$ & $0.04[-0.09,0.17]$ & $0.09[-0.04,0.22]$ \\
\hline Length & $0.1[-0.03,0.22]$ & $0.07[-0.06,0.19]$ & $-0.07[-0.2,0.05]$ & $-0.04[-0.16,0.08]$ & $-0.08[-0.21,0.06]$ & $-0.06[-0.19,0.07]$ & $-0.02[-0.15,0.11]$ & $0.02[-0.11,0.15]$ \\
\hline Birth weight & $-0.002[-0.14,0.14]$ & $-0.14[-0.28,0.01]$ & $0.03[-0.12,0.18]$ & $0.02[-0.12,0.16]$ & $0.11[-0.05,0.27]$ & $0.2[0.05,0.36]^{* *}$ & $0.001[-0.15,0.15]$ & $-0.07[-0.21,0.08]$ \\
\hline \multicolumn{9}{|l|}{$\begin{array}{l}\text { Child } \\
\text { variables at } \\
12 \text { years }\end{array}$} \\
\hline Height & $0.19[0.04,0.34]^{*}$ & $0.03[-0.12,0.18]$ & $0.19[0.04,0.34]^{*}$ & $0.15[0.01,0.29]^{*}$ & $-0.16[-0.32,0.01]$ & $-0.14[-0.3,0.01]$ & $-0.01[-0.16,0.15]$ & $0.23[0.08,0.38]^{* *}$ \\
\hline Weight & $-0.1[-0.26,0.06]$ & $0.14[-0.02,0.31]$ & $-0.09[-0.26,0.08]$ & $-0.18[-0.34,-0.02]^{*}$ & $0.16[-0.02,0.34]$ & $0.01[-0.16,0.19]$ & $-0.02[-0.2,0.15]$ & $-0.003[-0.17,0.17]$ \\
\hline $\begin{array}{l}\text { Head } \\
\text { circumference }\end{array}$ & $0.07[-0.01,0.14]$ & $0.02[-0.05,0.1]$ & $-0.01[-0.09,0.06]$ & $0.004[-0.07,0.08]$ & $-0.001[-0.08,0.08]$ & $0.03[-0.04,0.11]$ & $-0.01[-0.08,0.07]$ & $-0.04[-0.12,0.03]$ \\
\hline Haemoglobin & $-0.06[-0.16,0.05]$ & $-0.07[-0.18,0.04]$ & $0.05[-0.06,0.16]$ & $0.003[-0.1,0.11]$ & $0.02[-0.1,0.14]$ & $0.05[-0.07,0.16]$ & $-0.02[-0.13,0.1]$ & $-0.04[-0.15,0.07]$ \\
\hline $\begin{array}{l}\text { Fasting } \\
\text { glucose }\end{array}$ & $-0.02[-0.1,0.07]$ & $-0.05[-0.13,0.04]$ & $-0.01[-0.09,0.08]$ & $-0.06[-0.14,0.02]$ & $-0.02[-0.11,0.07]$ & $0.003[-0.08,0.09]$ & $-0.01[-0.09,0.08]$ & $-0.02[-0.11,0.06]$ \\
\hline Fasting insulin & $0.04[-0.06,0.14]$ & $-0.03[-0.13,0.07]$ & $-0.05[-0.14,0.05]$ & $0.06[-0.03,0.16]$ & $-0.02[-0.13,0.09]$ & $-0.003[-0.11,0.1]$ & $-0.01[-0.11,0.09]$ & $-0.12[-0.22,-0.02]^{*}$ \\
\hline Cholesterol & $-0.01[-0.11,0.08]$ & $0.02[-0.08,0.11]$ & $0.001[-0.1,0.1]$ & $-0.06[-0.15,0.03]$ & $0.05[-0.06,0.16]$ & $0.02[-0.08,0.12]$ & $0.02[-0.08,0.12]$ & $0.01[-0.09,0.1]$ \\
\hline Triglycerides & $0.01[-0.09,0.11]$ & $-0.07[-0.17,0.02]$ & $0.05[-0.05,0.15]$ & $-0.01[-0.1,0.09]$ & $-0.12[-0.23,-0.01]^{*}$ & $0.01[-0.1,0.11]$ & $-0.01[-0.11,0.09]$ & $-0.02[-0.12,0.08]$ \\
\hline Vitamin B12 & $-0.05[-0.14,0.03]$ & $0.02[-0.07,0.1]$ & $-0.07[-0.16,0.02]$ & $0.01[-0.07,0.1]$ & $-0.03[-0.13,0.06]$ & $0.001[-0.09,0.09]$ & $0.09[0,0.18]^{*}$ & $-0.01[-0.1,0.08]$ \\
\hline Folate & $-0.08[-0.16,0]^{*}$ & $-0.03[-0.11,0.05]$ & $-0.07[-0.15,0.01]$ & $-0.06[-0.13,0.02]$ & $0.07[-0.02,0.15]$ & $0.06[-0.03,0.14]$ & $-0.05[-0.14,0.03]$ & $-0.07[-0.15,0.01]$ \\
\hline Homocysteine & $-0.06[-0.15,0.04]$ & $0.08[-0.01,0.18]$ & $-0.04[-0.13,0.06]$ & $-0.07[-0.17,0.02]$ & $0.05[-0.05,0.16]$ & $0.02[-0.08,0.12]$ & $-0.003[-0.1,0.1]$ & $0.02[-0.08,0.12]$ \\
\hline Ferritin & $0.02[-0.06,0.11]$ & $-0.01[-0.09,0.07]$ & $0.02[-0.07,0.1]$ & $0.04[-0.04,0.12]$ & $-0.02[-0.11,0.07]$ & $-0.06[-0.15,0.03]$ & $0.04[-0.05,0.13]$ & $-0.01[-0.09,0.08]$ \\
\hline
\end{tabular}

Significance at $* * * \mathrm{p}<0.001, * * \mathrm{p}<0.01, * \mathrm{p}<0.05$

Each column represents a linear regression with the column heading as its dependent variable. The $\beta$-coefficients are included for each variable for each regression, with the $95 \%$ confidence interval in parentheses. All the regressions included maternal, paternal, child at birth as well as child at 12 -years variables. \# - The maternal variables are the mean of measurements made at 18 and 28 -week pregnancy. 
$\underline{\text { Table }-4 \text { Results of Bayesian analysis }}$

\begin{tabular}{|c|c|c|c|c|c|c|c|c|}
\hline Parental Exposures & $\begin{array}{l}\text { Color } \\
\text { Progressive } \\
\text { Matrices }\end{array}$ & $\begin{array}{l}\text { Picture } \\
\text { Completion }\end{array}$ & $\begin{array}{l}\text { Digit span } \\
\text { forward }\end{array}$ & $\begin{array}{l}\text { Digit span } \\
\text { backward }\end{array}$ & $\begin{array}{l}\text { Color Trail } \\
\text { making test } \\
\text { A (time } \\
\text { taken }\end{array}$ & $\begin{array}{l}\text { Color Trail } \\
\text { making test } \\
\text { B (time } \\
\text { taken }\end{array}$ & $\begin{array}{l}\text { Auditory } \\
\text { verbal } \\
\text { learning test }\end{array}$ & $\begin{array}{l}\text { Block } \\
\text { design (total } \\
\text { correct } \\
\text { score) }\end{array}$ \\
\hline \multicolumn{9}{|l|}{$\begin{array}{l}\text { Maternal variables during } \\
\text { pregnancy \# }\end{array}$} \\
\hline Age & --- & --- & --- & --- & --- & --- & --- & --- \\
\hline Education & $0.14(0.08)^{*}$ & $0.19(0.04) * * *$ & $0.14(0.06)^{*}$ & $0.15(0.06)^{*}$ & --- & --- & --- & --- \\
\hline Pre pregnancy BMI & --- & --- & --- & $-0.12(0.06)^{*}$ & --- & --- & --- & --- \\
\hline Activity score & --- & --- & --- & --- & --- & --- & --- & --- \\
\hline Calorie intake & --- & --- & --- & --- & --- & --- & --- & --- \\
\hline Haemoglobin & --- & --- & $-\mathrm{C}^{---}$ & $-0.1(0.06)^{*}$ & --- & --- & --- & --- \\
\hline Fasting glucose & --- & --- & --- & --- & --- & --- & --- & --- \\
\hline Fasting insulin & --- & --- & $\begin{array}{l} \\
0.13(0.04)^{* *}\end{array}$ & --- & --- & --- & --- & --- \\
\hline Cholesterol & --- & --- & --- & --- & --- & --- & --- & --- \\
\hline Triglycerides & --- & --- & --- & --- & --- & --- & --- & --- \\
\hline Vitamin B12 & --- & --- & --- & --- & --- & --- & --- & --- \\
\hline Serum folate & --- & --- & --- & --- & --- & --- & --- & --- \\
\hline Homocysteine & --- & --- & --- & --- & --- & --- & --- & --- \\
\hline Vitamin C & --- & --- & --- & --- & --- & --- & --- & --- \\
\hline Ferritin & --- & --- & --- & --- & --- & --- & --- & --- \\
\hline Interaction term (B12*folate) & --- & --- & --- & --- & --- & --- & --- & --- \\
\hline \multicolumn{9}{|l|}{ Paternal variables } \\
\hline Father's age & --- & --- & --- & --- & --- & --- & --- & --- \\
\hline Father's education & $0.16(0.07)^{*}$ & --- & --- & $0.24(0.05)^{* * *}$ & --- & --- & --- & $0.19(0.05)^{* *}$ \\
\hline Father's BMI & --- & --- & --- & --- & --- & --- & --- & --- \\
\hline Socio economic score & --- & --- & --- & --- & --- & --- & --- & --- \\
\hline
\end{tabular}




\begin{tabular}{|c|c|c|c|c|c|c|c|c|}
\hline Child Exposures & $\begin{array}{l}\text { Color } \\
\text { Progressive } \\
\text { Matrices }\end{array}$ & $\begin{array}{l}\text { Picture } \\
\text { Completion }\end{array}$ & $\begin{array}{l}\text { Digit span } \\
\text { forward }\end{array}$ & $\begin{array}{l}\text { Digit span } \\
\text { backward }\end{array}$ & $\begin{array}{l}\text { Color Trail } \\
\text { making test } \\
\text { A (time } \\
\text { taken }\end{array}$ & $\begin{array}{l}\text { Color Trail } \\
\text { making test } \\
\text { B (time } \\
\text { taken }\end{array}$ & $\begin{array}{l}\text { Auditory } \\
\text { verbal } \\
\text { learning test }\end{array}$ & $\begin{array}{l}\text { Block design } \\
\text { (total correct } \\
\text { score) }\end{array}$ \\
\hline \multicolumn{9}{|c|}{ Child variables at birth } \\
\hline Gender & --- & --- & --- & --- & --- & --- & $0.27(0.11) *$ & --- \\
\hline Head circumference & --- & --- & --- & --- & --- & --- & -- & --- \\
\hline Length & --- & --- & --- & --- & --- & --- & --- & --- \\
\hline Birth weight & --- & --- & --- & --- & --- & --- & --- & --- \\
\hline \multicolumn{9}{|c|}{ Child variables at 12 years } \\
\hline Height & $0.14(0.06)^{*}$ & --- & --- & --- & --- & $-0.11(0.07)^{*}$ & --- & $0.23(0.05) * * *$ \\
\hline Weight & --- & --- & --- & --- & --- & --- & --- & --- \\
\hline Head circumference & --- & --- & --- & --- & --- & --- & --- & --- \\
\hline Haemoglobin & --- & --- & --- & --- & --- & --- & --- & --- \\
\hline Fasting glucose & --- & --- & --- & --- & --- & --- & --- & --- \\
\hline Fasting insulin & --- & --- & --- & --- & --- & --- & --- & --- \\
\hline Cholesterol & --- & --- & --- & --- & --- & --- & --- & --- \\
\hline Triglycerides & --- & --- & --- & --- & --- & --- & --- & --- \\
\hline Vitamin B12 & --- & --- & --- & --- & --- & --- & --- & --- \\
\hline Folate & --- & --- & --- & --- & --- & --- & --- & --- \\
\hline Homocysteine & --- & --- & --- & --- & --- & --- & --- & --- \\
\hline Ferritin & --- & --- & --- & --- & --- & --- & --- & --- \\
\hline
\end{tabular}

${ }^{* * *}$ PIP $>99 \%,{ }^{* *}>95 \% \mathrm{PIP}<99 \%,{ }^{*}>75 \%$ PIP $<95 \%$. Each column represents a BMA regression with the column heading as its dependent variable. The posterior mean are shown in each cell of the table, and the square root of posterior variances are in parentheses.

Only robust predictors (PIP>75\%) are depicted in the table. 
Pune Maternal Nutrition Study (PMNS)

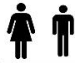

$1993-96$ $\operatorname{sen}$

1994-96

F1 Offspring

- 762 live births

- Followed up every 6 years
FO Parents

- 2456 women

recruited

- 814 pregnancies

- Mothers and Fathers

assessed

\section{木 \\ 2006-08}

12 year follow up

- 686 (90\% of live offspring)

assessed

- Physical growth and

development

- Cardio-metabolic risk factors

- Nutrition

- Neurocognitive performance 

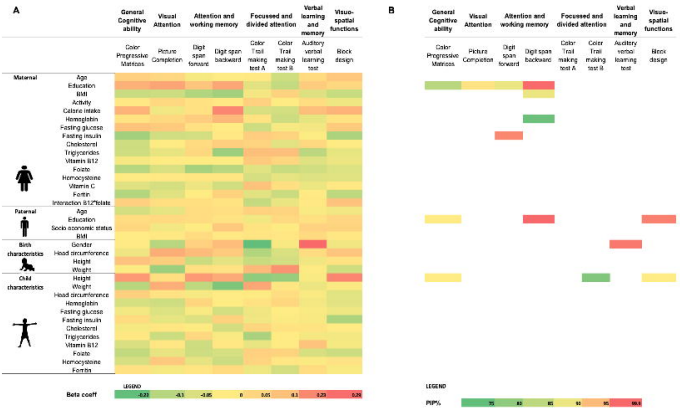